\title{
Micro-CT Analysis of Bone Healing in Rabbit Calvarial Critical- Sized Defects with Solid Bioactive Glass, Tricalcium Phosphate Granules or Autogenous Bone
}

\author{
Olli-Pekka Lappalainen', Sakari S. Karhula ${ }^{2,3}$, Marianne Haapea ${ }^{3}$, Sami Kauppinen ${ }^{2,3}$, Mikko \\ Finnilä2,4, Simo Saarakkala $^{2,3}$, Willy Serlo, George K. Sándor ${ }^{1}$ \\ ${ }^{1}$ Department of Oral and Maxillofacial Surgery, Research Group in Tissue Engineering, Faculty of Medicine, Medical Research \\ Center, University of Oulu, Oulu University Hospital, Oulu, Finland. \\ ${ }^{2}$ Department of Medical Imaging, Physics and Technology, Research Unit, Faculty of Medicine, Medical Research Center, \\ University of Oulu, Oulu, Finland. \\ ${ }^{3}$ Department of Diagnostic Radiology, Oulu University Hospital, Medical Research Center, University of Oulu, Oulu, Finland. \\ ${ }^{4}$ Department of Applied Physics, University of Eastern Finland, Kuopio, Finland. \\ ${ }^{5}$ Department of Pediatric Surgery, PEDEGO Research Center, Oulu University Hospital, Medical Research Center, Uinversity \\ of Oulu, Oulu, Finland.
}

\author{
Corresponding Author: \\ Olli-Pekka Lappalainen \\ University of Oulu \\ Aapistie 7, 5HAM, FI-90014, Oulu \\ Finland \\ Phone: + 358440225525 \\ Fax: +35885375504 \\ E-mail: olli-pekka.lappalainen@oulu.fi
}

\begin{abstract}
Objectives: The purpose of the present study was to evaluate bone healing in rabbit critical-sized calvarial defects using two different synthetic scaffold materials, solid biodegradable bioactive glass and tricalcium phosphate granules alongside solid and particulated autogenous bone grafts.

Material and Methods: Bilateral full thickness critical-sized calvarial defects were created in $15 \mathrm{New}$ Zealand white adult male rabbits. Ten defects were filled with solid scaffolds made of bioactive glass or with porous tricalcium phosphate granules. The healing of the biomaterial-filled defects was compared at the 6 week time point to the healing of autologous bone grafted defects filled with a solid cranial bone block in 5 defects and with particulated bone combined with fibrin glue in 10 defects. In 5 animals one defect was left unfilled as a negative control. Micro-computed tomography (micro-CT) was used to analyze healing of the defects.

Results: Micro-CT analysis revealed that defects filled with tricalcium phosphate granules showed new bone formation in the order of 3.89 (SD 1.17)\% whereas defects treated with solid bioactive glass scaffolds showed 0.21 (SD 0.16$) \%$, new bone formation. In the empty negative control defects there was an average new bone formation of 21.8 (SD 23.7)\%.

Conclusions: According to findings in this study, tricalcium phosphate granules have osteogenic potential superior to bioactive glass, though both particulated bone with fibrin glue and solid bone block were superior defect filling materials.
\end{abstract}

Keywords: bone regeneration; bone substitutes; bone transplantation; skull; X-ray microtomography.

Accepted for publication: 13 June 2016

To cite this article:

Lappalainen OP, Karhula SS, Haapea M, Kauppinen S, Finnilä M, Saarakkala S, Serlo W, Sándor GK.

Micro-CT Analysis of Bone Healing in Rabbit Calvarial Critical-Sized Defects with Solid Bioactive Glass, Tricalcium

Phosphate Granules or Autogenous Bone

J Oral Maxillofac Res 2016;7(2):e4

URL: http://www.ejomr.org/JOMR/archives/2016/2/e4/v7n2e4.pdf

doi: $10.5037 /$ jomr.2016.7204 


\section{INTRODUCTION}

There is a large and developing market for biodegradable bone substitutes in many fields of surgery. Special attention has been paid to develop bone substitutes for the cranio-maxillofacial skeleton since bone defects requiring grafting are easily created in routine procedures such as cranioplasty and facial asymmetry corrections. Numerous surgical techniques have been developed to reconstruct intra-operatively created cranio-maxillofacial bony defects [1-3]. Although bone substitutes, such as tricalcium phosphate (TCP) and bioactive glass (BAG), are already widely used in humans, there is little published histological and radiological data comparing their bony healing.

In vivo animal experiments using the rabbit calvarial critical-sized defect (CSD) model is a well-established and especially suitable for cranial bone defect model as the rapid healing process is similar to the common human patient group of pediatric patients with a postoperative cranioplasty condition. The rabbit CSD model serves as a basis to evaluate bone substitute products and compare their healing characteristics to the current gold standard, autogenous bone $[4,5]$. Inorganic synthetic bone substitutes have also been combined with autologous differentiated stem cells [6-8] or even with bone marrow or adipose derived stem cells without osteogenic induction [9-11] with the goal of speeding up the ossification process in larger bone defects.

There is a growing interest to gain an understanding of the fate of implanted cells within a porous solid scaffold and how extracellular mineralization induced by the scaffold affects the cells [12-17]. The BAG scaffolds are known to be non-cytotoxic, bacteriostatic and capable of supporting both cell attachment and proliferation in vivo. Early results indicate that the inclusion of BAG promotes precipitation of calcium phosphate on the scaffold surfaces leading to earlier cell differentiation and matrix mineralization [18-19].

Micro-computed tomography (micro-CT) serves as a new and accurate tool to analyze bone healing and to evaluate the bone formation on biomaterials such as TCP and BAG $[\underline{20}, \underline{21}]$.

The aim of this study was to evaluate bone healing in rabbit critical-sized bicortical calvarial defects comparing two different synthetic scaffold materials, solid bioactive glass and tricalcium phosphate granules versus solid or particulated autogenous bone. Since granular materials were used in the form of tricalcium phosphate and particulated autogenous bone chips no mechanical testing was planned in this study since granular scaffolds are known to be characteristically non-loadbearing materials.

\section{MATERIAL AND METHODS Animal study}

The following animal care and experimental protocol received ethical approval (Decision ESHL-200807701/Ym-23) from the Oulu University Hospital Ethical Committee. The study was performed in accordance with the Declaration of Helsinki and its later amendments.

A total of 15 white New Zealand male rabbits, aged 6 months or older and weighing at least 3.5 kilograms were included in this study. The anaesthesia was induced with subcutaneous injection of $15 \mathrm{mg} / \mathrm{kg}$ ketamine (Ketalar $50 \mathrm{mg} / \mathrm{ml}$, Pfizer Oy, Helsinki, Finland) and $0.25 \mathrm{mg} / \mathrm{kg}$ medetomide (Domitor ${ }^{\mathrm{B}}$ vet $1 \mathrm{mg} / \mathrm{ml}$, Orion Oyj, Espoo, Finland). The eyes were protected against drying by applying carbomer gel (Viscotears $2 \mathrm{mg} / \mathrm{g}$, Alcon Finland, Vantaa, Finland). An intravenous catheter was inserted to the lateral ear vein and a continuous infusion of sodium hydrochloride solution $0.9 \%$ (Natriumklorid $0.9 \%$, Fresenius Kabi Ab, Helsinki, Finland) was given under the operation. Antibiotic prophylaxis with $60 \mathrm{mg} / \mathrm{kg}$ cefuroxime (Zinacef $750 \mathrm{mg}$, GlaxoSmithKline Oy, Espoo, Finland) was given intravenously before the operation as a single dose. The animals were protected against temperature loss with special covers and warming pads in standard animal laboratory manner. Under general anaesthesia, the fur on the planned operation area on the rabbit head was shaved and cleaned properly with povidone iodide (Betadine $75 \mathrm{mg} / \mathrm{ml}$, Oy Leiras Finland $\mathrm{Ab}$, Helsinki, Finland) solution. A double cover and sterile instrumentation was used individually on each animal for the surgery according to the standard OR protocol. For local anaesthesia, $2 \mathrm{ml}$ of lidocaine (Lidocaine c. adrenalin 2\%, Orion Oyj, Espoo, Finland) was infiltrated in the skin around the planned incision line in the midline of the skull. From an approximately 5 $\mathrm{cm}$ long sagittal incision of the skin the periosteum was elevated and the rabbit was operated bilaterally bicortical full thickness circular critical-sized $(15 \mathrm{~mm}$ in diameter) defects, producing a total of 30 defects. Five defects were left empty as unfilled negative controls. Ten defects were filled with autologous particulated calvarial bone combined with fibrin glue to fix the bone mass within the defects mimicking particulate bone harvesting during cranioplasty.

Five defects were filled with an autologous calvarial bone block mimicking the standard cranioplasty 
maneuver. Five defects were filled with a porous solid circular $15 \mathrm{~mm}$ diameter resorbable commercially available three-dimensional porous BAG fiber scaffolds (INION BioRestore ${ }^{\mathrm{TM}}$, Tampere, Finland). These solid scaffolds were characterized by a nominal composition of $11.1-12 \mathrm{wt} \% \mathrm{Na}_{2} \mathrm{O} ; 15-17.1 \mathrm{wt} \%$ $\mathrm{K}_{2} \mathrm{O} ; 2.8-3.3 \mathrm{wt} \% \mathrm{MgO} ; 12.7-15.2 \mathrm{wt} \% \mathrm{CaO}$; $2.7-3.8 \mathrm{wt} \% \mathrm{P}_{2} \mathrm{O}_{5} ; 1-1.4 \mathrm{wt} \% \mathrm{~B}_{2} \mathrm{O}_{3} ; 0-0.6 \mathrm{wt} \%$ $\mathrm{TiO}_{2}$; and $48.5-52 \mathrm{wt} \% \mathrm{SiO}_{2}$. The solid scaffolds were made of melt spun bioactive glass fibers of 75 $\mu \mathrm{m}$ diameter which were sintered under defined conditions to produce a rigid scaffold with total porosity of $70 \%$ [22].

Five defects were filled with $0.5 \mathrm{~g}$ of biphasic $\beta$-TCP granules (Straumann Bone Ceramic ${ }^{\mathrm{TM}}$, Straumann AG, Basel, Switzerland). The granules were $100 \%$ crystalline being composed of $60 \%$ hydroxyl apatite and $40 \% \beta$-tricalcium phosphate. Straumann Bone Ceramic granules are available in 2 sizes: 0.4 to 0.7 $\mathrm{mm}$ and 0.5 to $1 \mathrm{~mm}$. In this study granule sizes ranging from 500 to $1000 \mu \mathrm{m}$ were used, while the pore size range was 100 to $500 \mu \mathrm{m}$. The total porosity of the product was $90 \%$ and the pores were interconnected.

After the operation the soft tissue and skin was sutured tightly to cover the operation areas with Vicryl ${ }^{\circledR}$ 3-0 (Ethicon Inc., Somerville, New Jersey, US) resorbable sutures. All animals received intensive supervision and care at the animal care facilities $24 \mathrm{~h} /$ day for the first three days following the surgery and for weeks after surgery three times a day. For postoperative analgesia each animal was given $0.1 \mathrm{mg} / \mathrm{kg}$ s.c. buprenorphine (Temgesic ${ }^{\circledR}, \mathrm{RB}$ Pharmaceuticals Ltd, Slough, England, UK) and against opioid related intestinal motility problems $3 \mathrm{mg}$ metoclopramide s.c. (Primperan ${ }^{\circledR} 5 \mathrm{mg} / \mathrm{ml}$, Sanofi-Aventis Oy, Helsinki, Finland,) three times a day for three postoperative days. Decrease in eating, drinking and moving or clear suffering from pain were determined to be the humane end points and the animals would have been terminated immediately if these signs were exhibited.

\section{Qualitative evaluation of the samples following harvest}

Healing of the calvarial CSDs was allowed up to the 6 weeks post placement time point to evaluate the early stage healing and ossification process in defects. The animals were terminated by giving an overdose of pentobarbital (Mebunat ${ }^{\circledR}$ vet, Orion Oyj, Espoo, Finland) intravenously after sedation with a subcutaneous injection of $0.25 \mathrm{mg} / \mathrm{kg}$ medetomide (Domitor $^{\circledR}$ vet $1 \mathrm{mg} / \mathrm{ml}$, Orion Oyj, Finland) and $15 \mathrm{mg} / \mathrm{kg}$ ketamine (Ketalar ${ }^{\circledR} 50 \mathrm{mg} / \mathrm{ml}$, Pfizer Oy, Helsinki, Finland). Immediately after termination, the skulls of the animals were exposed and a parietal bone block including the defect area and its surrounding bone was taken as a specimen. The specimens were fixed in $10 \%$ buffered formalin solution before histological preparation. All specimens were imaged using a micro CT scanner prior to histological sectioning.

One rabbit had traumatized its cranial wound resulting in an ectopic position of the implanted scaffold which led to a lack of contact with the surrounding bone resulting in disturbed healing. This defect was therefore excluded from the study.

\section{Micro-CT imaging}

After sacrifice the calvarial bone blocks including the bilaterally created defects with filling materials were harvested for ex vivo micro-CT imaging (Figure 1). The samples were scanned with an in vitro micro-CT device (Skyscan 1272, Bruker micro-CT) with scanning parameters of: $50 \mathrm{kV}, 200 \mathrm{~mA}, 1200$ projections, exposure $1400 \mathrm{~ms} /$ frame, average of 2 frames per projection, $0.5 \mathrm{~mm}$ Aluminium filter and isotropic $8 \mu \mathrm{m}$ voxel side length. Reconstructions for X-ray projections were made with Skyscan Nrecon-software (v. 1.6.9, Brüker micro-CT, Kontich, Belgium). Ring artefact and beam hardening corrections were applied in reconstruction. For analyses, volume of interest (VOI, 250 × 350 × 250 pixels) was selected from the reconstructed $\mathrm{CE} \mu \mathrm{CT}$ image stacks.

\section{Radiological analysis}

A volume of interest was manually selected from the defect and fully mineralized bone was thresholded to calculate the ratio of between the deposited bone and defect volume. Analyses were conducted with CTAn (v. 1.14.4.1, Brüker micro-CT, Kontich, Belgium).

\section{Statistical analysis}

Mean percentages of bone formation with standard deviation (SD) were calculated from micro-CT analyses. P-value of less than 0.05 was considered as statistically significant. The negative control group was compared separately with all filling materials using Mann-Whitney's U test. Overall difference between the defect materials was analyzed using Kruskall-Wallis $\mathrm{H}$ test. BenjaminiHochberg procedure was used to correct for multiple comparisons. IBM SPSS Statistics (v. 22.0) was used to conduct the statistical tests. 


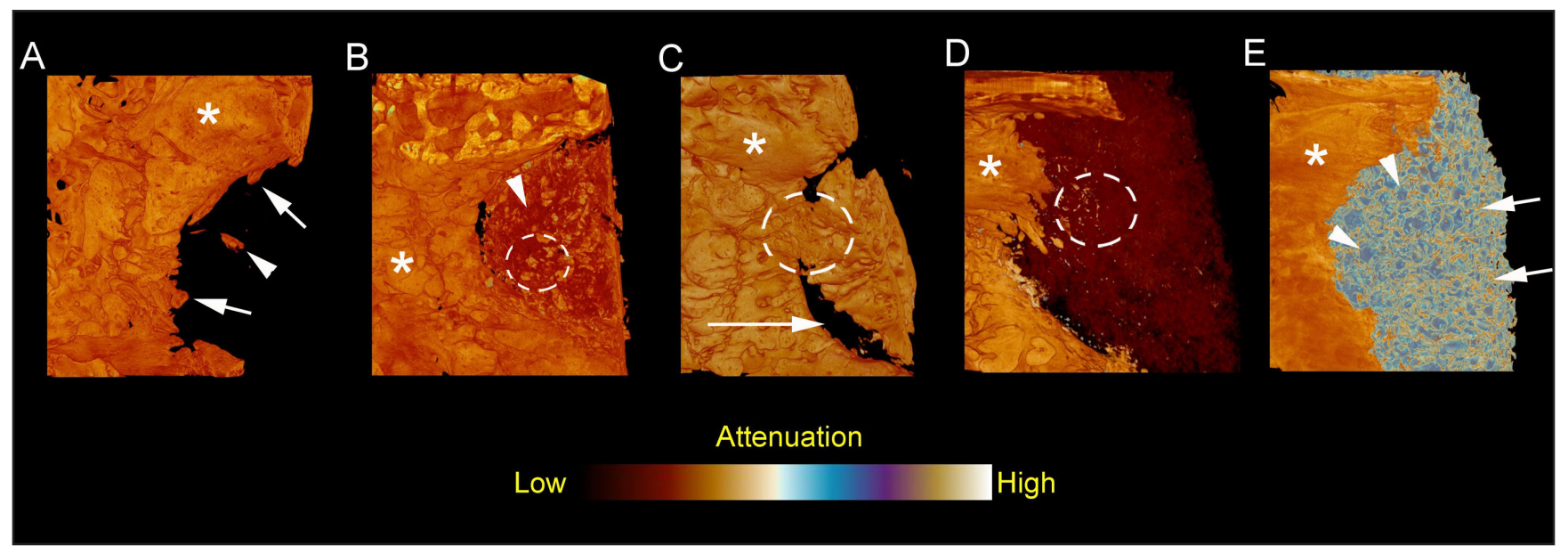

Figure 1. $A$ = Empty negative control defect showing a minimum of healing with uneven, centric ingrowth from the margins of the defect (arrows) and small bone islets in the center of the defect (arrowhead). Mature intact calvarial bone marked with asterisk.

$\mathrm{B}=$ Defect filled with combination of particulated autogenous bone (yellow and orange granules inside of dotted circle) and fibrin glue (dark red areas pointed with arrowhead). Mature intact calvarial bone marked with asterisk.

$\mathrm{C}=$ Defect with autologous bone block. The margins of the bone block have been partially resorbed (long arrow) and partial osseous continuity of the margin the bone block can be seen (inside of dotted circle). Mature intact calvarial bone marked with asterisk.

$\mathrm{D}=$ Resorbable BAG scaffold in defect (dark red). Ingrowth of new bone from the defect margin can be seen as well as very small ossifying spots in the middle of scaffold material (yellow/orange spots inside of dotted circle). Mature intact calvarial bone marked with asterisk.

$\mathrm{E}=$ TCP granules (blue spots pointed with arrowheads) filling a calvarial defect. Bone formation on the material surfaces can be seen (yellow and orange spots pointed with arrows). Mature intact calvarial bone marked with asterisk.

\section{RESULTS}

The negative control group revealed a noticeable variance in bone formation between individuals with micro-CT, 21.8 (23.7)\%, presented in Table 1. The micro-CT analysis at the 6 weeks post implantation time point revealed new bone formation in all defects. Particulated bone with fibrin glue and solid bone block were superior to BAG and TCP $(\mathrm{P}=0.012, \mathrm{P}=0.025, \mathrm{P}=0.019$ and $\mathrm{P}=0.024$, respectively; Table 1). The micro-CT analysis also showed significantly more new bone formation with TCP granules than with BAG scaffolds $(\mathrm{P}=0.024$, Table 1).

\section{DISCUSSION}

In treating cranial deformities, often the cranial vault must be reshaped by either recontouring or by sectioning the cranial vault into pieces [23]. When fragments are reassembled there may be palpable or visible defects between the bone pieces which may be unsightly when the scalp and pericranial tissues are redraped over the recontoured bone. Such unattractive bony defects can be filled with fragments of bone, particulated pieces of bone and bone dust collected during craniotomy. Some clinicians collect bone dust and particulated bone during cranioplasty and mix it together with fibrin glue to form a slurry-like

Table 1. Micro-computed tomography results

\begin{tabular}{l|c|c|c|c|c|c}
\hline \multirow{2}{*}{ Defect fillings } & \multirow{2}{*}{$\mathbf{N}$} & \multirow{2}{*}{ Mean (SD) } & \multicolumn{4}{c}{ Post hoc tests } \\
\cline { 6 - 8 } & & & $\mathbf{P}^{\mathbf{a}}$ & $\mathbf{P}^{\mathbf{b}}$ & $\mathbf{P}^{\mathbf{c}}$ & $\mathbf{P}^{\mathbf{d}}$ \\
\hline Negative control & 5 & $21.8(23.7)$ & & & & \\
\hline Particulated bone graft + fibrin glue & 10 & $24.2(18.7)$ & 0.768 & & & \\
\hline Bone block & 5 & $39(14.2)$ & 0.222 & 0.075 & & \\
\hline $\begin{array}{l}\text { Solid three-dimensional porous } \\
\text { BAG }\end{array}$ & 4 & $0.21(0.16)$ & 0.016 & 0.012 & 0.019 & \\
\hline TCP granules & 5 & $3.89(1.17)$ & 0.548 & 0.025 & 0.024 & 0.024 \\
\hline
\end{tabular}

aSignificance from the analysis of Mann-Whitney test, each filling material compared with negative control.

${ }^{\mathrm{b}}$ Comparison of particulated bone graft + fibrin glue vs. bone block, BAG and TCP, Benjamini-Hochberg procedure.

${ }^{\circ}$ Comparison of bone block vs. BAG and TCP, Benjamini-Hochberg procedure.

${ }^{\mathrm{d} C o m p a r i s o n}$ of BAG vs. TCP, Benjamini-Hochberg procedure.

$\mathrm{SD}=$ standard deviation; $\mathrm{BAG}=$ bioactive glass; $\mathrm{TCP}=$ tricalcium phosphate 
bone paste [24]. The fibrin glue in this paste helps fixate the bone pieces in the slurry and prevents their migrating from the wound. While the use of bone slurry is common practice in some craniofacial units, there is little evidence to show that it is beneficial. This study attempted to use an animal model to show that solid cortical bone grafts and bone slurry could have a role in managing cranial bony defects. This study also tried to illustrate the differences in bone defect healing with solid versus granular synthetic scaffolds.

Advances in imaging have led to improved resolution and to the ability to reveal both newly calcifying and already calcified tissue in healing bone defects. Micro-CT proves to be a novel and accurate tool for quantitative analysis of bone formation (Figure 1) whereas traditional histology better illustrates the cellular changes and histological properties of the healing area. The micro-CT results of this study illustrate some of the key differences in bone defect healing when the defect is left empty or when a solid or granular scaffold is used.

Remarkably, the results showed a notable variance in new bone formation between individual rabbits with empty control defects. The percentages in micro-CT range from 1.9 to 57.6 , which is due to individual variation in the healing of large bone defects. In some individual rabbits the defect heals much faster and better than in other individuals. However, what is common in the negative control group is the pattern of healing. It is from the periphery towards the center. Since these are critical sized defects the healing is incomplete at the six week time point.

In contra-distinction to this it must be realized that an empty void defect is dramatically different from a defect filled with a solid material. In the case of a solid scaffold or a bone block, much of the defect is occupied by the solid portion of the implant. This leaves little empty space available for "new bone growth" which is the parameter of interest measured in this experiment. In the case of a slowly resorbing solid BAG scaffold the only space allowed for tissue ingrowth is either into the three-dimensional porous space within the scaffold or around the solid implant on the dural surface of the implant. Solid biodegradable materials obstruct the ingrowth of bone to the defect area by its shear physical presence, unless the scaffolds resorb or have accessible porosity to allow the ingrowth. Thus sufficient blood flow by ingrowth of fibrous tissue and blood vessel is essential for the degradation and eventual replacement of a solid biomaterial by autologous tissues. In the case of solid bone blocks, which are analogous to replacing a devascularized bone flap during cranioplasty, these grafts become incorporated by replacement resorption and little physical space exists for new bone growth at the six week post grafting time point. Granular materials are inherently different from solid configurations of the same material [25-28]. This is true for both bone and synthetic biomaterials. The difference is two-fold. There is a far greater surface area available for cellularization with the granular configurations over solid structures. Moreover there is space between the granules to permit autologous tissue ingrowth and new bone formation which is evident at the six week time point for both particulate bone and $\beta$-TCP granules. The pore size of the implanted TCP granular scaffold plays an important role in revascularization as showed earlier by other investigators [29]. In general granular scaffolds are more quickly incorporated into the healing of a bony defect when compared to solid scaffolds. However, scaffolds in a granular format lack any load bearing capacity, while scaffolds in a solid form possess physical properties that allow them to be used to replace large cranial defects despite their slow resorption and replacement compared to granular scaffolds $[\underline{27}, \underline{30}]$.

The micro-CT images show the three-dimensional curved structure of the TCP granules which permit locking of the particles, preventing their migration out of the bony defects. The ingrowth of the fibrous tissue and new vessels between the granules enables the granules to remain locked with bone bridging which makes the structure of the graft construct even more stable. On the other hand mechanical stability and good vascularity seems to hasten the resorption of the BAG scaffold more than seen with the granules.

Both biomaterials used in this study, TCP and BAG, seemed to induce islets of bone growth histologically underneath the implanted area. Whether this phenomenon is caused by local irritation or stimulation of the stem cells in dura lying between the brain and the implant material remains unknown and will require more detailed investigation in the future.

A major limitation of this study is related to the absence of density differentiation between assayed grafts, since the material density of autologous bone, tricalcium phosphate, bioactive glass, can be similar to that of the newly formed bone, thus rendering data interpretation difficult. In a future in vivo study the authors will attempt to apply synchrotron based computed tomography imaging, where various artefacts can be avoided and superior resolution achieved even though the study protocol might require the additional use of bone deposition seeking labels such as strontium. This should allow for improved separation between newly formed bone 
and residual graft remains, thus greatly enhancing the relevance of the attained results.

Every experimental model has its limitations []․ The variability within the negative control group also leads to the question if the used model truly reflects a critical size defect - since up to approximately $60 \%$ of regeneration was attained. Longer time points such as 12 weeks would help answer the question of how complete the healing of an unfilled defect would be in the longer-term. Larger sample sizes in the future may also help lessen the effect of such inter-subject variability. Other sources of variability may arise, for instance, from the defect location, the inclusion of cranial sutures, the presence of dural tears, from thermal damage to the wound by electrocautery or by heat generation during the drilling of bone.

\section{CONCLUSIONS}

The findings of this study suggest that particulated autogenous bone with fibrin glue and solid autogenous bone blocks were superior in new bone formation to bioactive glass and tricalcium phosphate, while tricalcium phosphate granules were found to be superior to bioactive glass with more new bone formation in the rabbit critical-sized defect model.

\section{ACKNOWLEDGMENTS AND DISCLOSURE STATEMENTS}

The authors report no conflicts of interest related to this study.

The authors wish to express their gratitude for the financial support provided to this project by the ITI Foundation, Basel, Switzerland (ITI Grant number 619-2009), the University of Oulu EVO and VTR Grant Fund, the Stiftelsen Alma och K.A. Snellman Foundation, Oulu, Finland, Academy of Finland (Grants no. 268378 and 273571), The Sigrid Juselius Foundation and European Research Council under the European Union's Seventh Framework Programme (FP/2007-2013)/ERC Grant Agreement no. 336267, for their generosity.

\section{REFERENCES}

1. Sullivan SR, Taylor HO. Armadillo cranioplasty for expansion and remodeling in craniosynostosis. Plast Reconstr Surg. 2015 Jan;135(1):233-7. [Medline: 25539309] [doi: 10.1097/PRS.0000000000000830]

2. Smith DM, Cooper GM, Afifi AM, Mooney MP, Cray J, Rubin JP, Marra KG, Losee JE. Regenerative surgery in cranioplasty revisited: the role of adipose-derived stem cells and BMP-2. Plast Reconstr Surg. 2011 Nov;128(5):1053-60. [Medline: 22030488] [doi: 10.1097/PRS.0b013e31822b65e4]

3. Vercler CJ, Sugg KB, Buchman SR. Split cranial bone grafting in children younger than 3 years old: debunking a surgical myth. Plast Reconstr Surg. 2014 Jun;133(6):822e-827e. [Medline: 24867741] [PMC free article: 4493744] [doi: $10.1097 /$ PRS.0000000000000222]

4. Schmitz JP, Hollinger JO. The critical size defect as an experimental model for craniomandibulofacial nonunions. Clin Orthop Res. 1986 Apr;(205):299-308. [Medline: 3084153]

5. Jan A, Sándor GK, Brkovic BB, Peel S, Kim YD, Xiao WZ, Evans AW, Clokie CM. Effect of hyperbaric oxygen on demineralized bone matrix and biphasic calcium phosphate bone substitutes. Oral Surg Oral Med Oral Pathol Oral Radiol Endod. 2010 Jan;109(1):59-66. [Medline: 19846327] [doi: 10.1016/j.tripleo.2009.07.036]

6. Dietze S, Bayerlein T, Proff P, Hoffmann A, Gedrange T. The ultrastructure and processing properties of Straumann Bone Ceramic ${ }^{\circledR}$ and NanoBone ${ }^{\circledR}$. Folia Morphol (Warsz). 2006 Feb;65(1):63-5. [Medline: 16783740]

7. Jensen SS, Yeo A, Dard M, Hunziker E, Schenk R, Buser D. Evaluation of a novel biphasic calcium phosphate in standardized bone defects. A histologic and histomorphometric study in the mandibles of minipigs. Clin Oral Implants Res. 2007 Dec;18(6):752-60. [Medline: 17888014] [doi: 10.1111/j.1600-0501.2007.01417.x] [Medline: 17888014]

8. Strobel LA, Rath SN, Maier AK, Beier JP, Arkudas A, Greil P, Horch RE, Kneser U. Induction of bone formation in biphasic calcium phosphate scaffolds by bone morphogenetic protein-2 and primary osteoblasts. Tissue Eng Regen Med. 2014 Mar;8(3):176-85. [Medline: 22740314] [doi: 10.1002/term.1511]

9. Li X, Yao J, Wu L, Jing W, Tang W, Lin Y, Tian W, Liu L. Osteogenic induction of adipose-derived stromal cells: not a requirement for bone formation in vivo. Artif Organs. 2010 Jan;34(1):46-54. [Medline: 19821812] [doi: 10.1111/j.1525-1594.2009.00795.x]

10. Ye X, Yin X, Yang D, Tan J, Liu G. Ectopic bone regeneration by human bone marrow mononucleated cells, undifferentiated and osteogenically differentiated bone marrow mesenchymal stem cells in beta-tricalcium phosphate scaffolds. Tissue Eng Part C Methods. 2012 Jul;18(7):545-56. [Medline: 22250840] [doi: 10.1089/ten.tec.2011.0470]

11. Sándor GK, Numminen J, Wolff J, Thesleff T, Miettinen A, Tuovinen VJ, Mannerström B, Patrikoski M, Seppänen R, Miettinen S, Rautiainen M, Öhman J. Adipose stem cells used to reconstruct 13 cases with cranio-maxillofacial hard-tissue defects. Stem Cells Transl Med. 2014 Apr;3(4):530-40. [Medline: 24558162] [PMC free article: 3973720] [doi: $10.5966 / \mathrm{sctm} .2013-0173$ ] 
12. Mastrogiacomo M, Papadimitropoulos A, Cedola A, Peyrin F, Giannoni P, Pearce SG, Alini M, Giannini C, Guagliardi A, Cancedda R. Engineering of bone using bone marrow stromal cells and a silicon-stabilized tricalcium phosphate bioceramic: evidence for a coupling between bone formation and scaffold resorption. Biomaterials. 2007 Mar;28(7): 1376-84. [Medline: 17134749] [doi: 10.1016/j.biomaterials.2006.10.001]

13. Kauschke E, Rumpel E, Fanghänel J, Bayerlein T, Gedrange T, Proff P. The in vitro viability and growth of fibroblasts cultured in the presence of different bone grafting materials (NanoBone ${ }^{\circledR}$ and Straumann Bone Ceramic ${ }^{\circledR}$ ). Folia Morphol (Warsz). 2006 Feb;65(1):37-42. [Medline: 16783734]

14. Mrozik KM, Gronthos S, Menicanin D, Marino V, Bartold PM. Effect of coating Straumann ${ }^{\circledR}$ Bone Ceramic with Emdogain on mesenchymal stromal cell hard tissue formation. Clin Oral Investig. 2012 Jun;16(3):867-78. [Medline: 21584694] [doi: 10.1007/s00784-011-0558-3]

15. Sarkanen JR, Kaila V, Mannerström B, Räty S, Kuokkanen H, Miettinen S, Ylikomi T. Human adipose tissue extract induces angiogenesis and adipogenesis in vitro. Tissue Eng Part A. 2012 Jan;18(1-2):17-25. [Medline: 21902602] [doi: 10.1089/ten.tea.2010.0712]

16. Jensen SS, Bornstein MM, Dard M, Bosshardt DD, Buser D. Comparative study of biphasic calcium phosphates with different HA/TCP ratios in mandibular bone defects. A long-term histomorphometric study in minipigs. J Biomed Mater Res B Appl Biomater. 2009 Jul;90(1):171-81. [Medline: 19085941] [doi: 10.1002/jbm.b.31271]

17. Zimmermann CE, Gierloff M, Hedderich J, Açil Y, Wiltfang J, Terheyden H. Survival of transplanted rat bone marrow-derived osteogenic stem cells in vivo. Tissue Eng Part A. 2011 Apr;17(7-8):1147-56. [Medline: 21142699] [doi: 10.1089/ten.tea.2009.0577]

18. Haimi S, Moimas L, Pirhonen E, Lindroos B, Huhtala H, Räty S, Kuokkanen H, Sándor GK, Miettinen S, Suuronen R. Calcium phosphate surface treatment of bioactive glass causes a delay in early osteogenic differentiation of adipose stem cells. J Biomedical Materials Research. Part A. 2009 Nov;91(2):540-7. [Medline: 18985777] [doi: 10.1002/jbm.a.32233]

19. Poh PS, Hutmacher DW, Stevens MM, Woodruff MA. Fabrication and in vitro characterization of bioactive glass composite scaffolds for bone regeneration. Biofabrication. 2013 Dec;5(4):045005. [Medline: 24192136] [doi: $10.1088 / 1758-5082 / 5 / 4 / 045005]$

20. Shim JH, Moon TS, Yun MJ, Jeon YC, Jeong CM, Cho DW, Huh JB. Stimulation of healing within a rabbit calvarial defect by a PCL/PLGA scaffold blended with TCP using solid freeform fabrication technology. J Mater Sci Mater Med. 2012 Dec;23(12):2993-3002. [Medline: 22960800] [doi: 10.1007/s10856-012-4761-9]

21. Basu B, Sabareeswaran A, Shenoy SJ. Biocompatibility property of $100 \%$ strontium-substituted $\mathrm{SiO} 2$-A12 O3 -P2 O5 -CaO-CaF2 glass ceramics over 26 weeks implantation in rabbit model: Histology and micro-Computed Tomography analysis. J Biomed Mater Res B Appl Biomater. 2015 Aug;103(6):1168-79. [Medline: 25303146] [doi: $10.1002 / \mathrm{jbm} \cdot$ b.33270]

22. Tirkkonen L, Haimi S, Huttunen S, Wolff J, Pirhonen E, Sándor GK, Miettinen S. Osteogenic medium is superior to growth factors in differentiation of human adipose stem cells towards bone-forming cells in 3D culture. Eur Cell Mater 2013 Jan 30;25:144-58. [Medline: 23361609]

23. Serlo WS, Ylikontiola LP, Vesala AL, Kaarela OI, Iber T, Sándor GK, Ashammakhi N. Effective correction of frontal cranial deformities using biodegradable fixation on the inner surface of the cranial bones during infancy. Childs Nerv Syst. 2007 Dec;23: 1439-1445. [Medline: 17901962] [doi: 10.1007/s00381-007-0470-y]

24. Lappalainen OP, Korpi R, Haapea M, Korpi J, Ylikontiola LP, Kallio-Pulkkinen S, Serlo WS, Lehenkari P, Sándor GK. Healing of rabbit calvarial critical-sized defects using autogenous bone grafts and fibrin glue. Childs Nerv Syst. 2015 Apr;31(4):581-7. [Medline: 25391980] [doi: 10.1007/s00381-014-2588-z]

25. Hämmerle CH, Olah AJ, Schmid J, Flückiger L, Gogolewski S, Winkler JR, Lang NP. The biological effect of natural bone mineral on bone neoformation on the rabbit skull. Clin Oral Implants Res. 1997 Jun;8(3):198-207. [Medline: 9586464] [doi: 10.1034/j.1600-0501.1997.080306.x]

26. Leong KF, Cheah CM, Chua CK. Solid freeform fabrication of three-dimensional scaffolds for engineering replacement tissues and organs. Biomaterials. 2003 Jun;24(13):2363-78. [Medline: 12699674] [doi: 10.1016/S0142-9612(03)00030-9]

27. Sándor GK, Tuovinen VJ, Wolff J, Patrikoski M, Jokinen J, Nieminen E, Mannerström B, Lappalainen OP, Seppänen R, Miettinen S. Adipose stem cell tissue-engineered construct used to treat large anterior mandibular defect: a case report and review of the clinical application of good manufacturing practice-level adipose stem cells for bone regeneration. J Oral Maxillofac Surg. 2013 May;71(5):938-50. [Medline: 23375899] [doi: 10.1016/j.joms.2012.11.014]

28. McGuire TP, Gomes PP, Lam DK, Sándor GK. Cranioplasty for midline metopic suture defects in adult cleidocranial patients. Oral Surg Oral Med Oral Pathol Oral Radiol Endod. 2007 Feb;103(2):175-9. [Medline: 17234531] [doi: $10.1016 /$ j.tripleo.2006.02.014]

29. Feng B, Jinkang Z, Zhen W, Jianxi L, Jiang C, Jian L, Guolin M, Xin D. The effect of pore size on tissue ingrowth and neovascularization in porous bioceramics of controlled architecture in vivo. Biomed Mater. 2011 Feb;6(1):015007. [Medline: 21206002] [doi: 10.1088/1748-6041/6/1/015007] 
30. Vallittu PK. High-aspect ratio fillers: fiber-reinforced composites and their anisotropic properties. Dent Mater. 2015 Jan;31(1):1-7. [Medline: 25088348] [doi: 10.1016/j.dental.2014.07.009]

\section{To cite this article:}

Lappalainen OP, Karhula SS, Haapea M, Kauppinen S, Finnilä M, Saarakkala S, Serlo W, Sándor GK.

Micro-CT Analysis of Bone Healing in Rabbit Calvarial Critical-Sized Defects with Solid Bioactive Glass, Tricalcium Phosphate Granules or Autogenous Bone

J Oral Maxillofac Res 2016;7(2):e4

URL: http://www.ejomr.org/JOMR/archives/2016/2/e4/v7n2e4.pdf

doi: $10.5037 /$ jomr.2016.7204

Copyright $($ C Lappalainen OP, Karhula SS, Haapea M, Kauppinen S, Finnilä M, Saarakkala S, Serlo W, Sándor GK. Published in the JOURNAL OF ORAL \& MAXILLOFACIAL RESEARCH (http://www.ejomr.org), 30 June 2016.

This is an open-access article, first published in the JOURNAL OF ORAL \& MAXILLOFACIAL RESEARCH, distributed under the terms of the Creative Commons Attribution-Noncommercial-No Derivative Works 3.0 Unported License, which permits unrestricted non-commercial use, distribution, and reproduction in any medium, provided the original work and is properly cited. The copyright, license information and link to the original publication on (http://www.ejomr.org) must be included. 